\title{
Willingness to Pay for Maternity Waiting Homes in Rural Indonesia
}

\author{
Arlina Dewi ${ }^{1}$, Supriyatiningsih ${ }^{2}$, Sri Sundari ${ }^{3}$, Dianita Sugiyo ${ }^{4}$, Ralph. J. Lellee ${ }^{5}$ \\ ${ }^{1}$ Correspondence Author : arlinadewi@umy.ac.id \\ ${ }^{1}$ Master of Hospital Management, Universitas Muhammadiyah Yogyakarta, Bantul, Indonesia \\ ${ }^{2}$ School of Medicine, Medicine and Health Sciences Faculty, Universitas Muhammadiyah Yogyakarta, Bantul, Indonesia \\ ${ }^{3}$ School of Medicine, Medicine and Health Sciences Faculty, Universitas Muhammadiyah Yogyakarta, Bantul, Indonesia \\ ${ }^{4}$ School of Nursing, Medicine and Health Sciences Faculty, Universitas Muhammadiyah Yogyakarta, Bantul, Indonesia \\ 5 Muenster University Hospital, Germany
}

\begin{tabular}{l}
\hline I N D E X I N G \\
\hline Keywords: \\
Maternal waiting \\
home; \\
Willingness to Pay; \\
Rural areas
\end{tabular}

Kata kunci:

Rumah tunggu

kelahiran;

Kesediaan

membayar;

Area pedesaan;

\begin{abstract}
A B S T R AC T
Distance to a health care facility has long been discussed as a key barrier to maternal health care utilization in rural areas. Maternity Waiting Homes (MWHs) has been proved to reduce maternal mortality. The objective of this study was to investigate pregnant women's willingness to pay (WTP) for maternity waiting homes (MWHs). The cross-sectional study was conducted in two rural areas in South Sulawesi, Indonesia. The data were collected through a survey, which was distributed to pregnant women and their families. A total of fifty-one pregnant women and fortynine families participated in the study as two groups of respondents. The results of this study show that $66.7 \%$ of pregnant women agreed that they should stay at MWHs. For the group of pregnant women, the amount of WTP which was capable to be paid was 100,000 IDR in a month, whereas for the group of family, the amount of WTP which they could pay for staying at MWH was 200,000 IDR in a month. The pregnant women's acceptance to stay in MWH is good, but their willingness to pay is still very low.
\end{abstract}

Jarak ke fasilitas perawatan kesehatan telah lama didiskusikan sebagai penghalang utama dalam pemanfaatan perawatan kesehatan ibu di daerah pedesaan. Rumah Tunggu Bersalin (MWH) terbukti mampu menurunkan angka kematian ibu. Tujuan penelitian ini adalah untuk mengetahui kesediaan ibu hamil untuk membayar (WTP) terhadap Rumah Tunggu Bersalin (MWH). Studi cross-sectional dilakukan di dua wilayah pedesaan di Sulawesi Selatan, Indonesia. Pengumpulan data dilakukan melalui survei yang dibagikan kepada ibu hamil dan keluarganya. Sebanyak lima puluh satu wanita hamil dan empat puluh sembilan keluarga berpartisipasi dalam penelitian sebagai dua kelompok responden. Untuk hasil penelitian ini, terdapat 66,7\% ibu hamil yang setuju jika harus tetap di MWHs. Untuk satu kelompok ibu hamil, jumlah WTP yang mampu dibayarkan adalah $R p 100.000$ dalam sebulan. Apalagi untuk satu kelompok keluarga, besaran kesediaannya membayar yang bisa mereka bayarkan untuk tinggal di MWH adalah Rp 200.000 dalam sebulan. Penerimaan ibu hamil untuk tinggal di MWH memang baik, namun kesediaan mereka untuk membayar masih sangat rendah.

(C) 2020 JMMR. All rights reserved

\section{INTRODUCTION}

Maternal deaths currently arise worldwide due to the lack of human resources for pregnant women, which are not provided by the government and medical providers. Besides, most pregnant women do not utilize the maternity waiting homes even though these homes have been provided well. One of the crucial matters is that pregnant women prefer to stay at home during their pregnancy until giving birth. There are 830 women who die due to 
pregnancy and childbirth causes every day and many births still occur at home in the low and middle-income countries (Alkema et al., 2016; Johnson et al., 2013). Therefore, to reduce maternal mortality, pregnant women should stay at MWHs during their pregnancy.

MWHs are a place where pregnant women can stay before giving birth to fend off the high risk of pregnancy. Maternity waiting homes are residential facilities located near qualified medical facilities or health center that provides emergency obstetric care (Lori et al., 2018; Mannava et al., 2015). Also, pregnant women with a high risk of pregnancy can await their delivery and be transferred to a nearby medical facility earlier before complications arise.

MWHs contribute more than $80 \%$ to the reduction of maternal death among users in developing countries. Its contribution to the reduction of stillbirth is useful. More than $70 \%$ of stillbirth is reduced among the users of maternity waiting homes (Dadi et al., 2018). Likewise, staying at MWHs can help pregnant women to avoid maternal mortality, nevertheless MWHs are not used by pregnant women as the solution to reduce maternal mortality in Indonesia. Previous studies have shown that the barriers to MWH use are due to uncomfortable places, other important factors due to the limited costs of pregnant women and their families or husbands forbidding pregnant women to live in MWH (El Shiekh \& van der Kwaak, 2015; Sialubanje et al., 2016).

Indonesia is recorded as the country with the highest rate of maternal mortality in Southeast Asia. Additionally, Bulukumba in South Sulawesi is one of the regencies with high maternal deaths. Many remote areas have been provided with several MHWs, but these are not utilized by pregnant women. From the statements mentioned previously, the utilization rate of MWHs is inadequate to decrease maternal mortality. Furthermore, to increase the utilization rate of MWHs, it should include some acceptance requirements for pregnant women Bulukumba, which can be applied in the use of MWHs. The objective of this study was to investigate the pregnant women's Willingness to Pay (WTP) for maternity waiting homes (MWH).

\section{RESEARCH METHOD}

This study was conducted with a descriptive quantitative design. The data were taken from the survey field. For the research samples, there were 100 people consisted of 51 pregnant women and 49 families, especially the husbands based on simple random sampling. This research took place in Bulukumba $(n=67)$ and Bantaeng $(n=33)$ regency, South Sulawesi, with the number of respondents determined proportionally. The amount of WTP is calculated from the maximum value stated by each respondent.

\section{Demographic Characteristics}

\section{RESULT AND DISCUSSION}

The average pregnancy age of the respondents was 6 months (median). Twenty-eight years old was the average age of the pregnant women, and thirty-two years old was the average age of the families. Twenty-seven percent of the pregnant women finished their own study in Senior High School, and fifty-one percent of the families' education background was bachelor degree. In terms of profession, $92.2 \%$ of the pregnant women were housewives and 
$50.2 \%$ of the families worked in the informal sector. Thus, most pregnant women and their families had good educational and professional backgrounds.

\section{The Acceptance of MWH}

$62 \%$ of pregnant women and $67,3 \%$ their families had not heard about the MWHs. These percentages present the pregnant women and their families who had not had information about MWH. Also, $66.7 \%$ of the pregnant women and $47.8 \%$ of their families strongly agreed and agreed that pregnant women should stay at $\mathrm{MWH}$ when they were in the seventh month of the pregnancy. Additionally, $70.6 \%$ of the pregnant women and $80.5 \%$ of their families strongly agreed and agreed to have trained non-medical providers (or Community Health Workers/CHW) accompanying them at MWH.

\section{Willingness to Pay for MWH}

Regarding the willingness to pay for MWH, the pregnant women's and family's answer showed that there is only $37.3 \%$ average of pregnant women and $32.6 \%$ average of families who agreed to pay for staying at MWH. The amount of the group of pregnant women's willingness to pay for was 100,000 IDR in a month (median) with the minimum amount of 5,000 IDR, and the maximum amount was 500,000 IDR. Moreover, for the amount of the family group's willingness to pay, it was 200,000 IDR in a month (median) with the minimum amount of 20,000 IDR and the maximum amount of 1,000,000 IDR. Thus, the willingness to pay of pregnant women and families was very low, which was around 3,500 IDR to 7,000 IDR per day. For more information on maternity waiting home, it is mentioned and explained on the following table.

Table. 1 The acceptance of maternity waiting home

\begin{tabular}{|l|l|l|}
\hline \multicolumn{1}{|c|}{ Questions } & \multicolumn{1}{|c|}{ Pregnant women (answer) } & \multicolumn{1}{c|}{ Family (answer) } \\
\hline Have you ever heard about MWH? & $62 \%$ (not yet) & $67.3 \%$ (not yet) \\
\hline $\begin{array}{l}\text { Do you agree if high risk of pregnant } \\
\text { women stay in MWH when they are } \\
\text { in 7th month of pregnancy to ease the } \\
\text { access to the health service facility? }\end{array}$ & $\begin{array}{l}66.7 \% \text { (strongly agree and } \\
\text { agree) }\end{array}$ & $\begin{array}{l}47.8 \% \text { (strongly agree and } \\
\text { agree) }\end{array}$ \\
\hline $\begin{array}{l}\text { Do you agree if MWH is accompanied } \\
\text { by community health worker, but they } \\
\text { have been trained before? }\end{array}$ & $\begin{array}{l}70.6 \% \text { (strongly agree and } \\
\text { agree) }\end{array}$ & $\begin{array}{l}80.5 \% \text { (strongly agree and } \\
\text { agree) }\end{array}$ \\
\hline $\begin{array}{l}\text { If you, pregnant women's family have } \\
\text { to stay in maternal waiting home } \\
\text { (MWH), do you agree to pay the } \\
\text { payment for your daily life needs } \\
\text { during staying at MWH? }\end{array}$ & $37.3 \%$ (trongly agree and agree) & $\begin{array}{l}32.6 \% \text { (strongly agree and } \\
\text { agree) }\end{array}$ \\
\hline $\begin{array}{l}\text { If agree, how much the maximum } \\
\text { amount which you give during staying } \\
\text { in MWH per month? }\end{array}$ & IDR 100,000 * & IDR 200,000 * \\
\hline
\end{tabular}

Median rate

The pregnant women and their families in average had no knowledge about MWHs since there was no information they received from the government or even from medical providers. Conveying information about MWHs is one of the ways to deliver what social 
communities need to know about in order to make the information known by the social communities (Lori et al., 2013). Conducting socializations is an effective way to define whole context of maternal waiting homes, so social communities or the people who are related to it, especially pregnant women and their family know maternal waiting home and its regulations (Ekunwe, 2017). Community and social support is a crucial element in the success of MWHs. Support from community groups played a significant role in the development, construction and operation of MWHs, as well as communication between the community and health staff (McGowan, 2018). Giving information about MWHs to pregnant women was one of the ways to introduce what MWH is used for.

Pregnant women should stay in maternal waiting home when they are in the 7th month of their pregnancy to avoid serious risks they may face (Tiruneh et al., 2016). Hence, pregnant women need to live in MWH due to the health of their pregnancy. Of course, there were midwifery care providers who always stay in $\mathrm{MWH}$ to fulfill the needs of pregnant women in any kind of activities they do. Consequently, pregnant women should know exactly when they have to come to MWHs to ward off the high risk of pregnancy.

To implement MWH, it should include community health workers (CHW) who can accompany pregnant women during their stay at MWH. Also, the community health workers (CHW) must be the skillful ones who had been trained to serve the pregnant patients. The statements mentioned previously are in line with the arguments of El Shiekh and van der Kwaak that in order to achieve great goals in conducting maternal waiting homes, it should provide skilled medical providers in order to achieve good treatment to be applied to the pregnant women (El Shiekh \& van der Kwaak, 2015). Besides, skillful medical providers have various ways to handle pregnant women (Gaym et al., 2012). Therefore, skilled midwifery care providers are needed in maternal waiting homes to accompany pregnant women during staying at maternal waiting home. To avoid unnecessary services, it should include nonmedical providers to help CHWs and their patients, pregnant women.

Living cost at MWHs is the important aspect for the pregnant women or community who live in remote areas, especially in South Sulawesi, Bulukumba. Besides, not many of them are people of high economic status; they might be from a low economic group. Then, MWH should provide a solution to overcome the previous problems mentioned (Lori et al., 2016). MWH users mentioned absences of sufficient necessary facilities, poor quality and varieties of food. Because of insufficient facilities, the cost of living was high for most users (Kebede \& Mihrete, 2020). This study declared that the living cost during staying at maternal waiting home is covered only for patients who cannot afford to pay for the registration and services, and MWH should provide good services. Again, those are some of the ways to make patients feel satisfied with the services at MWHs.

Additionally, if MWH could not provide the solutions mentioned previously, it should provide other alternatives as the solutions (Satti et al., 2013). Satti, et al said that to decrease the cost of maternal waiting home, there should be some options, such as the provision of food to reduce indirect cost and the presence of midwifery care providers in order to help and prevent pregnant women not to stay at maternal waiting home, which become the solution. Also, they maintained that pregnant women who stay at MWHs should be charged with a free operational cost for staying at MWHs regarding the low economic status, or it should be an option for the middle and high economic groups to provide the appropriate 
operational financing. For instance, if the pregnant women are from the low economic group, the payment for the daily life needs during staying at the shelter should be free for them in any kind of services (Penn-Kekana et al., 2017). Indirect and direct costs pose substantial and sometimes insurmountable obstacles for many prospective users of the service (Lori et al., 2013). Therefore, the living cost for staying at maternal waiting home should be reviewed in order to attract pregnant women to stay in it.

\section{CONCLUSION}

For the group of pregnant women, the amount of WTP they are capable to pay for is 100,000 IDR in a month. Moreover, for the group of family, the amount of WTP they are able to pay for staying at MWH is 200,000 IDR in a month. The pregnant women's acceptance to stay in MWH is good, but their willingness to pay is still very low. The limitation in this study is the unequal economic status of the community, which requires more support and health promotion from health workers and cadres to ensure that maternal and child health can be achieved with community participation. It is recommended that further researchers provide effective communication training by empowering CHWs who are close to the community, the hope is that CHW will be able to change the attitude of pregnant women and their families to prioritize health by utilizing health facilities.

\section{ACKNOWLEDGMENT}

Acknowledgments to the Ministry of Research and Technology of Higher Education who have funded this research and support from Universitas Muhammadiyah Yogyakarta. Thank you to the Muhammadiyah Maternal Neonatal Center (MMNC), Bulukumba South Sulawesi Public Health Office, midwives, and CHWs who have supported this research to produce useful work to improve the health of mothers and children.

\section{REFERENCES}

Alkema, L., Chou, D., Hogan, D., Zhang, S., Moller, A. B., Gemmill, A., Fat, D. M., Boerma, T., Temmerman, M., Mathers, C., \& Say, L. (2016). Global, regional, and national levels and trends in maternal mortality between 1990 and 2015, with scenario-based projections to 2030: A systematic analysis by the un Maternal Mortality Estimation Inter-Agency Group. The Lancet, 387(10017), 462-474. https://doi.org/10.1016/S0140-6736(15)00838-7

Dadi, T. L., Bekele, B. B., Kasaye, H. K., \& Nigussie, T. (2018). Role of maternity waiting homes in the reduction of maternal death and stillbirth in developing countries and its contribution for maternal death reduction in Ethiopia: A systematic review and meta-analysis. BMC Health Services Research, 18(1). https://doi.org/10.1186/s12913. $018-3559-\mathrm{y}$

Ekunwe, A. B. (2017). The Efficacy of Maternity Waiting Homes in Decreasing Maternal and Perinatal Mortality in Low-Income Countries-A Systematic Review. The University of Arizona.

El Shiekh, B., \& van der Kwaak, A. (2015). Factors influencing the utilization of maternal health care services by nomads in Sudan. Pastoralism, 5(1). https://doi.org/10.1186/s13570-015-0041-x 
Gaym, A., Pearson, L., \& Soe, K. W. W. (2012). Maternity waiting homes in Ethiopia-Three decades experience. Ethiopian Medical Journal, 50(3), 209-219.

Johnson, F. A., Padmadas, S. S., \& Matthews, Z. (2013). Are Women Deciding against Home Births in Low and Middle Income Countries? PLOS ONE, 8(6), e65527. https://doi.org/10.1371/journal.pone.0065527

Kebede, K. M., \& Mihrete, K. M. (2020). Factors influencing women's access to the maternity waiting home in rural Southwest Ethiopia: A qualitative exploration. BMC Pregnancy and Childbirth, 20(296). https://doi.org/10.1186/s12884-020-02988-8

Lori, J. R., Boyd, C. J., Munro-Kramer, M. L., Veliz, P. T., Henry, E. G., Kaiser, J., Munsonda, G., \& Scott, N. (2018). Characteristics of maternity waiting homes and the women who use them: Findings from a baseline cross-sectional household survey among SMGL-supported districts in Zambia. PLOS ONE, 13(12), e0209815. https://doi.org/10.1371/journal.pone.0209815

Lori, J. R., Munro-Kramer, M. L., Mdluli, E. A., Gertrude, G. K., \& Boyd, C. J. (2016). Developing a community driven sustainable model of maternity waiting homes for rural Zambia. Midwifery, 41, 89-95. https://doi.org/10.1016/j.midw.2016.08.005

Lori, J. R., Wadsworth, A. C., Munro, M. L., \& Rominski, S. (2013). Promoting access: The use of maternity waiting homes to achieve safe motherhood. Midwifery, 29(10), 10951102. https://doi.org/10.1016/j.midw.2013.07.020

Mannava, P., Durrant, K., Fisher, J., Chersich, M., \& Luchters, S. (2015). Attitudes and behaviours of maternal health care providers in interactions with clients: A systematic review. Globalization and Health, 11(1). https://doi.org/10.1186/s12992-015-0117-9

McGowan, K. (2018, March 1). Unlocking the Full Potential of Maternity Waiting Homes. Maternal Health Task Force. https://www.mhtf.org/2018/03/01/unlocking-the-fullpotential-of-maternity-waiting-homes/

Penn-Kekana, L., Pereira, S., Hussein, J., Bontogon, H., Chersich, M., Munjanja, S., \& Portela, A. (2017). Understanding the implementation of maternity waiting homes in low- and middle-income countries: A qualitative thematic synthesis. BMC Pregnancy and Childbirth, 17(1). https://doi.org/10.1186/s12884-017-1444-z

Satti, Dr. H., McLaughlin, M. M., \& Seung, Dr. K. J. (2013). THE ROLE OF MATERNITY WAITING HOMES AS PART OF A COMPREHENSIVE MATERNAL MORTALITY REDUCTION STRATEGY IN LESOTHO (PIH Report Volume 1; Issue 1, p. 24). Partner in Health. https://www.pih.org/sites/default/files/201707/PIH_Report_Sept_IndividualPgs.pdf

Sialubanje, C., Massar, K., Kirch, E. M., Van Der Pijl, M. S. G., Hamer, D. H., \& Ruiter, R. A. C. (2016). Husbands' experiences and perceptions regarding the use of maternity waiting homes in rural Zambia. International Journal of Gynecology and Obstetrics, 133(1), 108-111. https://doi.org/10.1016/j.ijgo.2015.08.023

Tiruneh, G. T., Taye, B. W., Karim, A. M., Betemariam, W. A., Zemichael, F., Wereta, T. G., \& Lemango, E. T. (2016). Maternity waiting homes in Rural Health Centers of Ethiopia: The situation, women's experiences and challenges. Ethiopian Journal of Health Development, 30(1), 19-28. 